\title{
Fragmentation or Coherence? Does International Dispute Settlement Achieve Comprehensive Justice?
}

\author{
Simon A. Benson \\ Correspondence: Simon A. Benson BA LLM MDiv (Lecturer in Law, Torrens University Australia, Sydney, Australia)
}

Received: Mar. 29, 2020

Accepted: May 22, 2020

Online Published: May 24, 2020

doi:10.11114/ijlpa.v3i1.4873

URL: https://doi.org/10.11114/ijlpa.v3i1.4873

\begin{abstract}
The debate about whether international law is fragmented or coherent is no arid discussion. If fragmentation is in the ascendancy, many commentators argue that something needs to be done. It is, of course, vital for the success of any legal system to achieve some level of predictability and certainty and to consistently deliver comprehensive justice. A legal system must, first and foremost, be a justice system, if there is any point to its existence. If it is not, then there may be another debate about whether it may be called a 'legal' system or a 'justice' system at all. I will review the debate between various leading commentators and analyse their proposals. My review of a number of different aspects and areas of international law shows that although fragmentation is apparent, the level of coherence in international law is far more surprising than fragmentation, which is inevitable, just as it is in the development of national law in, say, a federal polity. Just when international law seems to be fragmented somewhere, coherence is being achieved elsewhere. The result may be characterised as a kind of 'equilibrium' in which antagonistic and cohesive forces in international law keep one another in check, somehow balancing the other out. International law is capable of delivering comprehensive justice even if, at times, it may seem unlikely or elusive.
\end{abstract}

Keywords: international law, fragmentation, coherence, comprehensive justice, international dispute settlement, multijurisdictional disputes, erga omnes, jus cogens, comity, delocalise, Vienna Convention, UNCLOS.

\section{Introduction}

\subsection{Introduction}

Like beauty, it has been said that the 'fragmentation' and 'coherence' of international law are 'not aspects of the world, but lie in the eye of the beholder' (Koskenniemi et al, 2006). The fragmentation of international law refers to the diversification, expansion and specialisation of international law, and the divergence of interpretation of multilateral arrangements (Koskenniemi et al, 2006). Fragmentation also refers to the way in which international law fails to accommodate a wider array of interests than the parties to the initial dispute. This failure includes the piecemeal approach to international dispute settlement where issues can be 'salami-sliced' in order to facilitate forum shopping and often to avoid or enliven a particular convention or dispute settlement regime. This fragmentation of international law is said to stem from increasing difficulty reconciling 'normative conflict' and the fact that the institutional structure of international dispute settlement is 'horizontal' and nonhierarchical (Koskenniemi et al, 2006; Tanaka, 2018).

As Tanaka puts it, international law has 'no higher authority above individual States' (Tanaka, 2018). That is, there is no pouvoir constituant or constitutional power, such as that which establishes and empowers domestic courts and tribunals. It follows that 'rules of international law... are interpreted and applied by States on their own' (Tanaka, 2018). Some commentators blame the proliferation of international courts and tribunals and international law's shift from generality to specialised fields for the disparate threads of international law's interpretation and application (Benvenisti \& Downs, 2007). Others see the issue as 'exaggerated' and a question of perception, as the increased globalisation of world affairs appears novel in light of the old order. Whatever else is true, agreed mechanisms and approaches are necessary to settle international legal disputes (Tanaka, 2018). As international law has 'no single legislative will behind' it, it can only be effective where there is consent of states to agree to be bound by it and submit to institutions charged with adjudicating on it (Koskenniemi et al, 2006).

I will consider the fragmentation debate in light of a range of areas of international law to discern which perspective has better support and whether fragmentation is demonstrable. Commentators on both sides of the debate, including the authors of the 2006 ILC Report, seek to highlight tensions that they argue arise from an examination of similar cases 
and the way in which different judicial bodies, that might be expected to demonstrate some level of consistency, have done otherwise. The survey I propose here may clarify whether international law is fragmented or coherent, or both. Fragmentation is inevitable and may operate as an important check, shaping and informing the law's development, as it does in domestic law. I will also survey some normative conflict resolution proposals and examine whether they provide solutions to fragmentation.

\subsection{The Concepts}

'Fragmentation' is the lack of consistency in international law as a result of 'the diversification and expansion of international law,' law-making treaties between often different and disconnected regional groups ('regionalisation'), the legal effect of multilateral treaty revision and the law relating to revision, specialising of international law and divergent approaches to legal interpretation by different international legal institutions applying different legal norms (Jenks, 1953). 'Coherence' is more about 'deference' than 'falling in line' or 'exact correspondence' between domestic, regional and international legal norms. It entails comity between domestic and international dispute settlement institutions acting cooperatively. 'Comprehensive justice' is the holistic settlement of the dispute as defined by the parties, and regard for any interests affected (Note 1). 'Regionalisation' occurs because 'law-making treaties are tending to develop in a number of historical, functional and regional groups, which are separate from each other and whose mutual relationships are in some respects analogous to those of separate systems of municipal law' (Koskenniemi et al, 2006).

\subsection{The Fragmentation v. Coherence Debate}

Fragmentation is seen by some as a phenomenon that 'sabotages the evolution of a more democratic and egalitarian international regulatory system' and 'undermines the normative integrity' of international law (Benvenisti \& Downs, 2007). Benvenisti and Downs argue that powerful state actors can 'threaten or abandon' competing institutions and 'forum shop' for a venue more receptive to their interests (Benvenisti \& Downs, 2007). They also argue that the more powerful states have actively promoted fragmentation to suit their interests (Benvenisti \& Downs, 2007). State sovereignty is in tension with external bodies over which states have no control and whose decisions are seen as eroding it. Self-interest of states often conflicts with wider international interests given that, 'International law is decentralised and no state recognises any authority higher than their sovereignty' (Lando, 2017). This tension is said to be part of the problem (Nygh \& Butt, 1997; Romano et al, 2014).

Posner and others argue that states abandon courts and tribunals that cease to meet their interests, setting up others causing an international adjudicative proliferation (Schultz \& Ridi, 2017). This proliferation of international courts and tribunals causes 'overlapping jurisdictions and ambiguous boundaries' (Benvenisti \& Downs, 2007). The problem is that 'most treaties establishing international courts and tribunals do not provide rules governing their relationship with jurisdictional counterparts' and individual courts have 'rigid jurisdictional provisions (Schultz \& Ridi, 2017). The MOX Plant case is a case in point. It has been argued that such fragmentation leads to inconsistent outcomes that 'jeopardise the unity of international law and its role in inter-State relations' (Benvenisti \& Downs, 2007). Specialisation of international law, increasing regionalism and promotion of regional interests have resulted in further fragmentation (Benvenisti \& Downs, 2007). Perhaps many of these different views represent different aspects of the same, comprehensive reality. Most commentators agree that international law is fragmented, but disagree about the problem and the extent to which international dispute settlement mechanisms (adjudication) deliver comprehensive or piecemeal justice. The debate persists.

At the outset, the positions adopted by commentators fall within a spectrum and are as follows. Many commentators who view international law as fragmented, of whom Koskenniemi is in the vanguard, are dismissive, however, of factors such as regionalism and see fragmentation as overtstated (Koskenniemi et al, 2006; Burchill, 2011). Tanaka argues that although some level of fragmentation is inevitable in international law, it is wrong to lay too much emphasis on it, and 'fears of fragmentation' are unjustified and have not been realised (Tanaka, 2018). Koskenniemi argues that there is a remarkable degree of 'regulatory coordination' between international institutions (Koskenniemi \& Leino, 2002). For others, fragmentation is a 'harmless side effect' of 'the institutional expression of political pluralism internationally' and 'increased demand for expertise in international institutions (Koskenniemi \& Leino, 2002).' A case has been made for the 'Europeanisation' of international law as a factor of fragmentation (Wouters et al 2011; Roberts, 2011). The commentators book-end the debate by observing fragmentation while at the same time affirming evidence of efforts to achieve coherence.

\section{Selected Case Studies}

Individual, seemingly straightforward disputes between two state parties can be transformed into a multijurisdictional dispute with jurisdictional and procedural complications (MOX Plant). Conversely, international law has developed ways of resolving complex, multifaceted disputes with multiple non-state actors, with widely differing claims, to assess and award damages in a streamlined way, delivering effective justice (Mixed Claims Commissions and Mass Claims Tribunals). International criminal law can produce inconsistent verdicts. UNCLOS is something of a mixed bag with International Commercial Arbitration overall the exemplar. 


\subsection{Fragmentation - The MOX PLANT case (Ireland v UK)}

The MOX Plant case (Ireland v UK) (Note 2) is a classic example of fragmentation of international law. The case concerned potential environmental effects of a nuclear facility at Sellafield in the UK and raised issues about the law of the sea, sea pollution and EC law. It involved four different treaties, many resolution mechanisms and three different sets of rules addressing the same facts, spawning proceedings in three different fora (Koskenniemi et al, 2006). The overlap of international dispute settlement regimes that could all adjudicate on the same facts was an object lesson in fragmentation at its worst (Koskenniemi, 2007).

Ireland commenced arbitration proceedings against the UK in an Arbitral Tribunal under Annex VII of UNCLOS and sought provisional measures. There were also arbitral proceedings pursuant to the compulsory dispute settlement regime under the Convention on the Protection of the Marine Environment of the North-East Atlantic (OSPAR Convention). The UK commenced proceedings in the European Court of Justice (ECJ) under the European Community and Euratom Treaties (Koskenniemi et al, 2006). This case involved UNCLOS, but as it was a case of undoubted fragmentation and overlap in international law, the evaluation of its legacy, as will be seen, is far more nuanced.

In discussing this case, the ILC Report asks whether the issue is 'principally about the law of the sea, about (possible) pollution of the North Sea, or about inter-EC relationships?' (Koskenniemi et al, 2006; Koskenniemi, 2007). The ILC highlights the problem of fragmentation as each institution would have approached the application of the same rules differently due to 'differences in the respective context, object and purposes, subsequent practice of parties and travaux preparatoires' (Koskenniemi, 2007); Koskenniemi et al, 2006). But the decision of the UNCLOS tribunal to suspend the proceedings undoubtedly managed 'the potential conflict with other international jurisdictions', given the likely cross-vesting of the dispute to the ECJ and has important juridical ramifications for comity as a way of ameliorating the effects of fragmentation (Schultz \& Ridi, 2017).

\subsection{Fragmentation - International Criminal Law}

International criminal courts and tribunals, such as the ICC and specialist criminal tribunals were established to hear international criminal cases as well as more localised conflicts, such as occurred in the former Yugoslavia and Rwanda. The ICC was established by the Rome Statute, adopted in 1998, and the ICTY and ICTR were created by the Security Council in 1993 and 1994 under Chapter VII of the UN Charter, respectively Res. 827 of 25 May 1993 and Res. 955 of 8 November 1994. Such courts and tribunals have grown, but they have not resulted in an 'international judicial system as such' and differ over the test of criminal liability and the elements of war crimes and crimes against humanity (Valencia-Ospina \& Malintoppi, 2012). For example, the ICC's test for criminal liability of a state, established in Application of the Convention on the Prevention and Punishment of the Crime of Genocide (Bosnia and Herzegovina $\mathrm{v}$ Serbia and Montenegro), Judgment of 26 February 2007, 2007 ICJ Report, 43, is 'effective control'. This conflicts with ICTY and ICTR jurisprudence where the test for individual criminal responsibility in cases such as Prosecutor v Tadić, Case No. IT-94-1-A, Appeals Chamber, Judgment of 26 February 2007, 2007 ICJ Report, 43, is 'overall control'. This may be characterised as an example of fragmentation of international criminal law (Sadat, 2013). Why criminal liability of a member state differs from individual liability is unclear. The test of mens rea for individual and corporate criminal liability should be the same. Both involve an inquiry into the accused's state of mind. In corporate law, the relevant degree of intention must be present in the corporate mind, viz. the board: Tesco Supermarkets Ltd v Nattrass [1971] UKHL 1. Jurisprudential differences aside, the ICTY and ICTR are positive forms of proliferation of courts (Valencia-Ospina \& Malintoppi, 2012). They are courts that 'together, influenced the establishment of the ICC' and achieved conspicuous success in bringing all perpetrators of war crimes and crimes against humanity to justice, for example, in the former Yugoslavia, where 'there remain no accused at large' (Shany, 2005).

\subsection{Fragmentation - UN Convention on the Law of the Sea (UNCLOS)}

UNCLOS has given rise to a 'multiplicity of dispute settlement systems' (Charney, 1996). Tanaka argues that although there is a risk that international law is prone to fragmentation, the risk should not be overstated (Tanaka, 2018). Having said that, Tanaka draws attention to the differing interpretations of Article 281 of UNCLOS evident in the 1999 ITLOS award in the Southern Bluefin Tuna case (New Zealand v Japan; Australia v Japan), ITLOS case No 3 and 4, Request for Provisional Measures, Order of 27 August 1999 (1999) 38 ILM; Southern Bluefin Tuna case (Australia v Japan; New Zealand v Japan), Award on Jurisdiction and Admissibility (4 August 2000), (2000) 39 ILM and the outcome of the South China Sea arbitration (Philippines v China), PCA case No 2013-19, Award, 12 July 2016 (Tanaka, 2018). In Southern Bluefin Tuna, ITLOS accepted that the dispute resolution mechanisms under UNCLOS were available as the 1993 Convention did not preclude prima facie jurisdiction of ITLOS (Tanaka, 2018). The Panel took a different approach to Article 281 in the South China Sea arbitration, where it found that Article 281 requires a clear statement of exclusion (Tanaka, 2018).

It may be seen at once that different Panels have taken different views of the provisions of the same Convention. This 
detracts from Tanaka's opinion that although total harmony cannot be achieved because of the 'inherent limitation' of international law - as it is a decentralised and non-hierarchical system - harmonisation is best left to 'the wisdom of international judges' (Tanaka, 2018). But UNCLOS does not only suffer from the problem of conflicting interpretation. The operation of UNCLOS as a dispute mechanism aimed at preventing fragmentation has been largely subverted.

UNCLOS is not a panacea when it comes to settling all international disputes involving the law of the sea. In 'legal disputes under UNCLOS, the critical questions are whether the dispute concerns the interpretation and application of the Convention and whether any of the exceptions and limitations applies' (Klein, 2014). Boyle argues that UNCLOS allows member states to use 'salami-slicing' of legal issues to side-step Part XV's compulsory jurisdiction; the very feature of UNCLOS that was 'designed to prevent fragmentation of the conventional law of the sea' (Boyle, 1997).

For Klein, the effectiveness of a convention such as UNCLOS is difficult to assess, but its compulsory jurisdiction under Part XV has been invoked in a series of unexpected cases to adjudicate disputes involving interesting jurisdictional issues. Such cases include Chagos Archipelago (Mauritius v. United Kingdom); South China Sea (Philippines v. China) and Dispute Concerning Delimitation of the Maritime Boundary Between Bangladesh and Myanmar in the Bay of Bengal (Bangladesh v. Myanmar) (Klein, 2014). Klein argues that this development may militate against the wider effectiveness of UNCLOS (Klein, 2014).

Even though further negotiation was necessary, compulsory conciliation under Part XV in Report and Recommendations of the Compulsory Conciliation Commission between Timor-Leste and Australia in the Timor Sea, 9 May 2018 (Timor-Leste v Australia), which concerned, inter alia, the permanent maritime boundary between Australia and Timor-Leste in the Timor Sea, settled complex issues concerning the Timor Gap that had been left unresolved by previous treaties. By any standards, the outcome was an extraordinarily successful result.

\subsection{Coherence - Mixed Claims Commissions/Mass Claims Tribunals}

The forerunner to the modern Mixed Claims Commission (MCC) arose from the British government's dispute with the United States and Great Britain over the sinking of US naval ships in 1869 [Alabama Claims case (United States v Great Britain) (1872)] and also with Venezuela over the Panama Canal [British Guiana - Venezuela Boundary Dispute (Great Britain v Venezuela) (1897)]. MCCs were set up to avoid the use of force and typically involve states (Giorgetti, 2012). In contrast, Mass Claims Tribunals (MCTs) are usually characterised by large, lump sum, monetary compensation, invariably being paid to non-state actors suing states (Giorgetti, 2012). MCTs are constituted by a commission of 3-5 arbitrators whose ruling on a legal claim is binding (Giorgetti, 2012). The matters usually proceed by way of arbitration and have a number of advantages (Giorgetti, 2012). Arbitration is a familiar procedure and the so-called 'peace dividend' is seen as a positive step toward the reintegration of a losing country back into the fold. Also, complex political machinations, that would otherwise frustrate the proceedings, are not brought to bear on them (Giorgetti, 2012).

The United Claims Claims Commission, set up to rule on the dispute between Iraq and Kuwait after the 1990-91 Iraqi invasion, only had to determine the question of who got what compensation (Giorgetti, 2012). Iraq's liability was established by the terms of paragraph 16 of Security Council Resolution 687 (1991): 'Reaffirms that Iraq, without prejudice to the debts and obligations of Iraq arising prior to 2 August 1990, which will be addressed through the normal mechanisms, is liable under international law for any direct loss, damage, including environmental damage and the depletion of natural resources, or injury to foreign Governments, nationals and corporations, as a result of Iraq's unlawful invasion and occupation of Kuwait.' Iraq had, in effect, no right of reply (Giorgetti, 2012). The money to fund the payments was sourced from Iraq oil sales (Giorgetti, 2012). Apart from corruption exposed during the establishment of the 'Oil for Food' Program, the commission was an undoubted success (Giorgetti, 2012). In the Ethiopia/Eritrea Claims Commission, set up after the Ethiopia-Eritrea border war, liability (causation) had to first be established and so its operation was different from the UNCC. Unlike Iraq/Kuwait, each side in the Ethiopia/Eritrea Claims Commission made competing claims. As Iraq caused Kuwait enormous suffering, there is an undoubted 'victor's justice' element to MCCs.

Perhaps the best known example of an MCT is the Iran-United States Claims Tribunal (IUSCT). Claims arose after the 1979 Iranian revolution during which the Shah of Iran was ousted and given asylum in the US (Giorgetti, 2012). The US had invested heavily in Iran while the Shah was in power (Giorgetti, 2012). After the revolution, US nationals were unlawfully held and mistreated, Iran breached contracts with US companies and US property was unlawfully expropriated (Giorgetti, 2012). Invoking its 'long arm' jurisdiction, the US froze Iranian assets (Giorgetti, 2012). After numerous proceedings in US and foreign courts, US companies sought attachment against Iranian assets and property in the US and overseas. The stand-off resulted in Iran taking Americans hostage in Tehran and the US seizing Iranian assets (Tanaka, 2018).

Algeria offered to mediate the dispute and brokered an agreement as a result of which the IUSCC was established 
(Tanaka, 2018) (Note 3). Iranian assets and money were released in exchange for US hostages. The Commission was composed of 9 members with 3 from the US, 3 from Iran and 3 independent (neutral) members. Hostage claims were outside the scope of the agreement. The 'genuine link' test established in the Nottebohm case (Liechtenstein v. Guatemala), 1955 ICJ 4 (Judgment of 6 April 1955), affirmed by the IUSCC, has been endorsed in subsequent authoritative decisions of the ICJ. High levels of efficiency and enforcement are indisputable features of MCCs and MCTs as they are both capable of hearing and determining high volume, high value claims (Born, 2012). I have included MCCs and MCTs in this survey not because they are free from being prone to politicisation, but rather as exemplars of coherence in international dispute settlement (Giorgetti, 2012).

\subsection{Coherence - International Commercial Arbitration}

It is no surprise that arbitration is at the forefront of international dispute settlement, as a series of famous arbitrations in Alabama Claims case (United States v Great Britain) (1872), Bering Sea Fur Seal case (1893) and British Guiana Venezuela Boundary Dispute (Great Britain v Venezuela) (1897) served as forerunners to the 1899 Hague Convention. Born notes the success of so-called 'second-generation' tribunals which a wide range of domestic legal systems recognise and regularly act in aid of their provisions pursuant to domestic legislation (Born, 2012). This may be said of the Convention on the Recognition and Enforcement of Foreign Arbitral Awards (New York, 1958) (New York Convention). Sparse though its provisions are, the New York Convention has been a remarkably successful international dispute instrument boasting 163 member states as of March 2020.

Although the significant feature of coherence of the New York Convention is the extent to which all member states have agreed to reciprocity of enforcement, its practical operation is fragmented (Chinkin \& Sadurska, 1991). Despite its obvious advantages, international commercial arbitration does suffer from inconsistency in comparison with other international dispute resolution mechanisms and domestic proceedings with an international element, the latter of which, at least in most common law countries, follows a system of binding precedent. There is little consistency, even among signatories to instruments like the New York Convention, over issues such as arbitrability, intervention and enforcement. Member states differ over what areas of law, such as intellectual property and trade practices (antitrust), may be arbitrated. Other doubtful areas of arbitrability are claims affecting the status of a person or a corporation, insolvency and quasi-criminal conduct.

There is also inconsistency in circumstances where an award debtor has an arbitral award set aside, usually in the seat of the proper law of the arbitration, but the putative (or erstwhile) award creditor seeks to enforce the impugned award in another country (where the award debtor has assets) that does not recognise decisions of the courts of the country where the award has been set-aside [see Norway No 1, Charterer v. Shipowner, Halogaland Court of Appeal, 16/8/99; Charterer v. Shipowner, Y.B. Comm. Arb. XXVII (2002) 519 (Norway No. 1)]. This demonstrates the 'comity v. delocalise' tension that exists in international commercial arbitration that reflects the wider fragmentation $\mathrm{v}$ coherence debate within international law generally. As the enforcing court's discretion is not mandatory, even if an exception is shown, 'the enforcing court is not obliged to refuse enforcement' (Blackaby et al, 2015). Courts have ruled accordingly: Europcar Italia SpA v Alba Tours International Inc [1997] OJ No 133, 23 OTC 376 (Gen Div); China Agribusiness Development Corporation v Balli Trading [1998] 2 Lloyd's Rep. 76 [QBD (Comm Court)]; China Nanhai Oil Joint Service Corporation v Gee Tai Holdings Co Ltd (1995) XX YBCA 671, 672, 677 per Kaplan J.

The 'delocalise' school characterises countries such as France. The 'comity' school is typified by the US, whose courts regularly recognise awards that have been set aside. Although it is clearly bad faith to try to enforce an award that has been set aside, parties are still able to 'forum shop' in international commercial arbitration to find a jurisdiction where the setting-aside will not be enforced. This is because the sole concern of the Convention is to bring about a regime with as few impediments as possible to an arbitration agreement being upheld and non-domestic arbitral awards being recognized and enforced. The Convention's pro-enforcement bias finds its counterpoint in Article V, where grounds for refusal of recognition and enforcement have been codified. Courts of most member states have, however, held Article V's grounds to be exhaustive and construed them narrowly: Parsons \& Whittemore Overseas Co Inc v Societe Generale de L'Industrie du Papier (RAKTA) and Bank of America 508 F.2d 969, 973 ๆ25 (2nd Cir. 1974); Yusuf Ahmed Alghanim \& Sons v. Toys "R" Us, Inc., 126 F.3d 15, 23 (2d Cir. 1997); TermoRio S.A. E.S.P. v. Electranta S.P., 487 F.3d 928, 935 (D.C. Cir. 2007); Rosseel NV v Oriental Commercial \& Shipping (UK) Ltd [1991] 2 Lloyd's Rep. 625 (Comm) (English High Court).

Third party intervention is also problematic in international commercial arbitration, which has always regarded joinder as complicating the arbitration. Intervention, where a third party tries to take the initiative, is a lot more difficult than joinder with the consent of the parties. The English decision of Abu Dhabi Gas Liquefaction Co. Ltd. v. Eastern Bechtel Corporation (C.A.) [1982] 2 Lloyd's Rep. 425, concerning two arbitrations that were consolidated, is a case in point. An issue arose about the appointment of arbitrators. Without consent, the court could not compel joinder. Lord Denning's 
quintessentially novel solution was to appoint the same arbitrator to hear both. Naturally, courts take judicial notice of the parties' desire for comity and can appoint the same arbitrator. This situation can, of course, be avoided by drafting an appointment clause or an agreement to joinder.

\subsection{Mixed Outcomes - Third Party Intervention}

For international law to deliver comprehensive solutions, it has been argued that third party interests need to be heard and considered as well as those of the parties (Romano et al, 2014). Part of the rationale for this approach is that international law is perceived as 'statist', rather than taking the interests of non-state actors and individuals whose rights may be adversely affected into account (Chinkin \& Sadurska, 1991). Chinkin argues that although international dispute resolution is multi-party, adjudication should only deal with the disputants themselves (Chinkin \& Sadurska, 1991). Others argue that if international law seeks to find holistic solutions capable of taking a broad range of interests into account, then third parties, including non-state actors and individuals, should be allowed to provide information to the court or tribunal about other interests that may be affected and the implications of the outcome for the wider public (Ronan and Naggan, 2014).

There are a number of ways in which third party interests can be heard in the context of a dispute between the original parties. The filing of amicus curiae briefs is one method. One of the first cases where non-party interests were considered was in the US Shrimp case before the WTO [United States - Import Prohibition of Certain Shrimp and Shrimp Products, Recourse to Article 21.5 of the DSU by Malaysia. WT/DS58/RW, 15 June 2001; United States Import Prohibition of Certain Shrimp and Shrimp Products, Appellate Body Report, WT/DS58/AB/R, adopted 6 November 1998; original panel report, WT/DS58/R and Corr.1, as modified by the Appellate Body Report, WT/DS58/AB/R, adopted 6 November 1998]. The US annexed an NGO's report to their pleadings so that wider environmental concerns could be taken into consideration. Amicus briefs were rejected by the Panel, but allowed on appeal (Ronan and Naggan, 2014; Romano et al, 2014). While the Appellate Body said that it was not deciding issues such as environmental protection, adoption of measures by sovereign states to protect endangered marine life and bilateral action between sovereign states (within or outside the WTO) to protect both, the Appellate Body noted that sovereign states should take measures to ensure each such outcome.

The ruling by the WTO Appellate Body in US Shrimp approving the receipt of amicus briefs was confirmed in United States - Lead and Bismuth II [United States - Imposition of Countervailing Duties on Certain Hot-Rolled Lead and Bismuth Carbon Steel Products Originating in the United Kingdom, Appellate Body Report, WT/DS138/AB/R, adopted 6 November 1998]. Even though amicus briefs in the form of submissions may be made, there is no obligation for them to be accepted nor for the tribunal to take them into account. What these cases demonstrate is that sometimes non-state actors would do better working with or alongside government.

Squatrito argues that if the views of non-state actors are endorsed by one of the parties, then their views are more likely to be heard (Squatrito, 2018). A fortiori where the amicus submission has particular relevance to the issues being considered. The advantage is that states do not always give tribunals the full picture, and non-state actors can 'fill the gaps' with expert evidence (WTO), rendering non-state intervention in international dispute resolution less statist (Chinkin \& Sadurska, 1991). Squatrito notes that only a small percentage (around 20\%) of all amicus briefs were accepted and considered at the WTO (Squatrito, 2018). Allowing amicus briefs at the Panel stage in the WTO, for example, where most of them will be considered, if at all, cannot be said to 'open the floodgates' for a rash of amicus briefs to be submitted in every case. An $80 \%$ rejection rate demonstrates that the WTO is selective in its approach about who and what it will allow and/or hear and consider on an amicus basis.

There are procedural issues to be considered too. The Appellate Body in the Asbestos case [Panel Report, European Communities - Measures Affecting Asbestos and Asbestos-Containing Products, WT/DS135/R and Add.1, adopted 5 April 2001, as modified by the Appellate Body Report, WT/DS135/AB/R] has now laid down guidelines of the basis on which the WTO will receive amicus briefs. It is significant for coherence that the WTO has acknowledged that interests other than those of the parties to international disputes are affected. Regional settings may be important for amicus briefs to be submitted and considered. It is widely accepted now that the involvement of civil society is increasingly important in international law and that it is important to hear from non-state actors. Ironically, the US has been more restrictive about use of amicus briefs since the US Shrimp case.

Having touched on joinder in an arbitration context, joinder under the ICJ Statute is important too. Third party intervention is increasing in a wide range of cases before the ICJ. Two forms of joinder are permitted under the ICJ Statute. Article 62 permits joinder where a legal interest may be affected, which need not be dispositive (Tanaka, 2018). Where a multilateral treaty falls to be considered, Article 63 permits intervention of a member state as of right (Tanaka, 2018). Provided a state is a party to a convention whose construction is in question, it does not need to show any legal interest and may intervene (Tanaka, 2018). The ICJ Statute is, therefore, permissive when it comes to the issue of 
joinder. Article 62 is a low bar to intervention, as is Article 63, as New Zealand's joinder to the Whaling in the Antarctic case shows [Whaling in the Antarctic (Australia v Japan), Declaration of Intervention of New Zealand, Order of 6 February 2013, ICJ Reports 2013]. Also, a state joined under Article 63 is bound by the decision (Ronan and Naggan, 2014; Tanaka, 2018).

\section{Evaluation: Reconciling Disparate Views \& Interests}

It is apparent from the foregoing review that international law is fragmented, but also capable of producing coherence. The MOX Plant case demonstrates that overlapping conventions, regional arrangements and dispute settlement regimes can complicate the resolution of the same dispute. Each institution would have sought to impose its solution on the same set of facts according to what Koskenniemi calls its own 'institutional perspective' depending on the objectives of the legal regime and culture of the institution itself. International criminal law too is not without fragmentation when it comes to what test to apply to criminal liability and, unlike national law, distinguishes between state and individual criminal responsibility and applies different tests to the resolution of that question depending on the tribunal. We have also seen how the attempt by UNCLOS to prevent fragmentation has, to a great degree, been thwarted by legal strategies designed to subvert or avoid the compulsory dispute resolution regime that has been established under it (Oxman, 2001; Charney, 1995).

The ambitious program Mixed Claims Commissions and Mass Claims Tribunals set for themselves has achieved a substantial measure of success, given the high number of claimants and the factual and legal complexity involved. Despite Born's glowing endorsement, even international commercial arbitration, though successful, is still plagued by jurisdictional disparity over such areas as arbitrability and enforcement. The New York Convention's pro-enforcement bias is intended to address fragmentation, but, as has been seen, there are still inconsistent approaches by national courts of member and non-member states about what matters are amenable to arbitration and the legal effect of setting-aside awards that are sought to be enforced by award creditors.

Where the New York Convention does deal with fragmentation successfully is by reducing the grounds on which an arbitral award may be challenged. Even so, many countries have developed their own divergent jurisprudence with regard to the interpretation of these provisions. Overall, though, the success of international commercial arbitration has largely been the result of a legal framework regulated by domestic and international law. International commercial arbitration has been said to be a mix of both 'hard' (New York Convention) and 'soft' law (UNCITRAL). So-called 'hard' law is controlling, whereas so-called 'soft' law is optional, and usually given force by domestic legislation, such as the UNCITRAL Model Law under sec. 2D(e) of the International Arbitration Act 1974 (Cth).

Third party intervention is a problematic area for international law. Chinkin and Sadurska argue that it erodes international law's consensual legitimacy without which it ceases to be effective (Chinkin \& Sadurska, 1991). Competing voices advocate the benefits of third party intervention as opening up international dispute settlement to a wider range of issues so that outcomes potentially deliver more holistic justice (Romano et al, 2014). It may be argued that the twin objectives that underpin international law, consensus and comprehensive justice, may not be coordinate and coextensive criteria. Ironically, the more comprehensive international dispute settlement is, the less consensus international law seems to garner. This is the Gordian knot at the heart of international law.

UNCLOS was an attempt to bind member states to compulsory dispute settlement procedures on ratification, yet member states still manage to try to find a way out (Posner, 2009). Such conduct with regard to tribunals such as ITLOS is an example of what happens when 'states become unhappy with an existing international court...they work around it by depriving it of jurisdiction and establishing additional courts or adjudication mechanisms as needed (Posner, 2009). The same is true of the ICJ's general jurisdiction given member states' proclivity for highly privative reservations on consent. The area where third party intervention has been successful and 'influential' is in criminal proceedings before the ICC, ICTY and ICTR where amicus curiae briefs have been sought and accepted resulting in amended indictments and convictions in very serious crimes (Ronen \& Naggan, 2014).

Perhaps international institutions such as the ICJ ought not be seen as 'actively courting' third party intervention as it may only promote further reservations on consent and discourage wider participation. International law cannot ignore third party interests any more than national law can but because of the nature of the dynamic in international law, the dispute settlement process has to strike a balance between resolving the instant dispute and accommodating wider interests too in such a way that states are not dissuaded from participation in the ICJ's general jurisdiction (Ronen \& Naggan, 2014). In this regard, Article 62 of the ICJ Statute has been said to be unduly restrictive and 'hardly justified on normative grounds' and that it should allow for intervention in matters of general international law (Ronen \& Naggan, 2014). However, the amendment of the ICJ Statute, which would be required, is extremely unlikely, particularly on such a controversial issue, and accordingly any solution to this issue is not going to happen any time soon. It might be argued that joinder under the ICJ Statute is to some extent 'self-policing' as third parties who seek to intervene under Article 63 
will be bound by the decision (Ronen \& Naggan, 2014). Third parties need to weigh the benefits of joinder with the burden of being bound by a decision.

\section{The Solution: Constitutionalism or Consensus?}

Fragmentation is challenged by a steadily increasing discourse about 'constitutionalism.' Egede and Sutch argue that fragmentation is 'shifting politics away from states to international adjudication' (Egede \& Sutch, 2013). In their view, 'the attempted 'constitutionalisation' of international law, 'most evident in solidarist and cosmopolitan approaches' to international law, is an attempt to 'counter this new politics by developing hierarchies of rules' (Egede \& Sutch, 2013). This approach views international law as programmatic in the way it is interpreted and applied. Constitutionalism is also programmatic for the workings of international institutions (such as the UN itself) and their agencies, including trade organisations (such as the WTO). This approach sits well with international law's 'strong presumption against normative conflict' (Koskenniemi et al, 2006). Constitutionalism seeks to bring a programmatic and coherent approach to international law through consensus.

Against that, Constitutionalism may simply be an exercise in reframing. Whether the UN Charter, for example, is viewed as a treaty or a 'constitution in the clothes of a treaty' may not vest it with any more normative status than it already has, but the debate is not without its uses (Dunoff \& Trachtman, 2009). For Gutterman, constitutional discourse provides 'an opportunity to reflect on the deep questions of fragmentation, consolidation, power, and legitimacy that bedevil attempts to promote international law as a coherent source of justice in the international realm' (Gutterman, 2012). Perhaps international law needs 'constitutional discourse' to match the national constitutional bias seen by some commentators as skewing international law along overly 'statist' lines (Dunoff \&Trachtman, 2009; Gutterman, 2012; Chinkin \& Sadurska, 1991). Constitutionalism is relevant to the fragmentation v. coherence debate as it bears on 'our conception of the character of international law, but also the underlying ideologies, values, and power relations upon which the international legal order rests and transformation will depend' (Gutterman, 2012).

Arguably, fragmentation of international law can be minimised by recognition of substantive primary 'conflict rules' for interpreting international law. The principles of jus cogens, erga omnes and comity are obvious examples. The concept of erga omnes obligations was developed by the ICJ in the 1970 Barcelona Traction case (Armstrong, 2011). Such obligations are owed to the international community as a whole, not just individual states before the ICJ, such that breach may enable all states to take action (Armstrong, 2011; Valencia-Ospina \& Malintoppi, 2012). Indeed, 'this concept has helped reinforce the idea that certain international obligations are especially important and that the broad community of States has an interest in and can speak to whether those obligations are being transgressed" (Murphy, 2012). The ICJ invoked the principle in the 1995 East Timor case, but has been cautious in subsequent discussion of the implications of erga omnes obligations (Armstrong, 2011).

Closely related to erga omnes is the principle derived from Article 31 (3)(c) of the Vienna Convention on the Law of Treaties 1969 (Vienna Convention), which introduced the doctrine of jus cogens into a treaty for the first time (Armstrong, 2011). McInerney-Lankford has described jus cogens as 'the principle of systemic integration' (McInerney-Lankford, 2012). But, in practice, jus cogens is 'seldom cited' by the ICJ (Armstrong, 2011). It may be time to reinvigorate the principle of jus cogens or cognate principles, despite the challenges regionalism poses (Koskenniemi et al, 2006). For Armstrong, states 'comprise an authentic legal community whose remit goes far beyond the classic concern with the rights of sovereign states' (Armstrong, 2011). Justice Allsop, writing extrajudicially, argues that 'in an increasingly transnational and international world, courts are more regularly meeting questions of principle and judgment that require a balance of national interest and respect for, or at least consideration of, the place of courts and of other countries.' The touchstone of the Vienna Convention is closely related to comity in that Article 27 prevents a party from invoking its own domestic law to justify a failure to perform a treaty.

The principle of comity may be a possible solution, provided its application is not seen as unnecessarily 'unbundling sovereignty' too much and is perceived as consistent with what most states characterise as their rule of law (Egede \& Sutch, 2013). Comity is a concept that has 'mutated over time' (Paul, 1991). Lord Mansfield first introduced the idea of comity into English law. The most celebrated judgments of Lord Mansfield with regard to comity are those in Somerset v Stewart (1772) 98 ER Rep 499 (KB) and Geyer v Aguilar (1798) 7 TR 680 at 695-696; [1798] EngR 148; 101 ER 1196 at 1204. Lord Mansfield held that comity did not oblige one nation to apply the laws of another, but rather that "[e]very nation must be the final judge for itself, not only of the nature and extent of the duty, but of the occasions, on which its exercise may be justly demanded." In other words, it was discretionary provided its application accorded with the interests of justice. In Somerset v Stewart (1772) 98 ER Rep 499 (KB) at 509, Lord Mansfield considered American slavery laws and held that the rights of an American slave owner could not be recognised by English courts as slavery was 'so odious, that nothing can be suffered to support it, but positive law.'

The classic statement or 'canon of construction' on comity, is the dissenting judgment of Justice Scalia in Hartford Fire 
Insurance Co. v. California 509 U.S. 764 (1993) affirming the US Supreme Court's statement in Murray v. The Schooner 'Charming Betsy' 6 U.S. 2 Cranch 64 (1804): 'An act of Congress ought never to be construed to violate the law of nations if any other possible construction remains, and consequently can never be construed to violate neutral rights or to affect neutral commerce further than is warranted by the law of nations as understood in this country'. Comity is not about bringing one set of laws into lockstep with another (Bradley, 1997). Its concern is that national courts and tribunals show a degree of deference to foreign law and foreign courts (Paul, 1991).

National courts have a role to play as agents of enforcement of international law. One commentator has observed that, 'The increased reliance on international law by national courts may thus be a sign of the times: in an era of growing global interdependence, the invocation of international law responds to an increasing need to manage laws and policies across national boundaries. International law accommodates this need by equipping national courts with a "common language" through which they can communicate with institutions and constituencies situated in other polities; it also provides "focal points" for coordination and cooperation.' (Shany, 2009).

In many commercial areas, such as banking, insurance and shipping law, a measure of comity has traditionally existed between different legal regimes. Maritime law, for example, had 'the force of law, not from extraterritorial reach of national laws, nor from abdication of its sovereign powers by any nation, but from acceptance by common consent of civilised communities of rules designed to foster amicable and workable commercial relations' [Lauritzen $v$ Larsen [1953] USSC 62; 345 US 571 (1953) at 581-582 per Justice Jackson].

Roberts points to an increasing tendency in the area of international and national criminal law to inform one another, leading to what she calls 'glocalisation' as international and national law cross-fertilise each other in a 'co-constitutive' way (Roberts, 2011). Courts and law enforcement agencies cooperate over cross-border criminal law enforcement (Hufnagel, 2017). Comity is facilitated now by 'internet and publishing developments [who] are also making domestic judgments on international law matters more accessible' (Roberts, 2011).

In the twenty-first century, comity 'has come to inform a broader class of cases in which courts have applied foreign law or refrained from exercising foreign jurisdiction.' For Meier, comity is not a rule, but a 'functional element that defines a system of international legal order' (Meier, 1982). It is not clear what else a 'functional element' of a 'legal order' could be in an adjudicative context unless what is being discussed as an aspect of it is some kind of rule or, short of being a rule, a well-known and time-honoured conflict doctrine or normative criterion for achieving coherence.

Justice Allsop has observed that, 'comity, as originally conceived, was designed to serve as a legal principle (an overarching norm and a philosophical legal theory) and not as a defined set of rules. Comity is, in truth, a 'little understood concept upon which so much depends, and which is often more a matter of legal fiction than of reality or principle' (Allsop, 2015). Irrespective of how comity might be characterised, it is a doctrine of reciprocity that has, as Shany argues, shaped judicial attitudes to 'regulate their procedures in ways conducive to the consideration of parallel proceedings' (Shany, 2005).

Comity still has work to do in an increasingly globalised world economy where most national economies are linked to the regional or global economy. International commerce is too important for national economic survival for any one nation to be an island in a 'highly interdependent global market' (Paul, 1991). Comity is as much a force for coherence in international law as national self-interest is for fragmentation. Furthermore, whereas consensus is hard to come by, comity is demonstrably a 'creature subtler than rules.' (Schultz and Ridi, 2017).

\section{Conclusion}

Most commentators agree that international law has undergone fragmentation and has become highly specialised and regionalised owing to increasing legal complexity and the proliferation of international legal instruments and institutions (Benvenisti \& Downs, 2007; Koskenniemi et al, 2006). This trend has been necessary to cover fields into which international law has ventured beyond its traditional remit. But this proliferation is simply part of an array of dispute settlement armoury all working in tandem in international law. In the Canadian Salmon case, for example, although Australia lost before the WTO Panel and Appellate Body, Australia was still able to use arbitration later in order to secure for itself valuable time and concessions, which in large measure ameliorated the effects of the WTO's determination and any enforcement. The Timor-Leste $v$ Australia conciliation too was a combination of diplomacy, negotiation and UNCLOS compulsory jurisdiction. So, it is not as if international law options are rigidly constrained or taking place in practice in some sort of legal straight jacket; there is a range of dispute settlement options available within the context of international law's broad church.

Some commentators argue that fragmentation is just a phenomenon that those who adjudicate on international law accept as they work toward achieving coherence in their determinations. In contrast, coherence is achievable by applying, where appropriate, normative principles, such as those enshrined in the Vienna Convention, in interpreting 
international conventions, and international law in general. As conflict rules, principles or doctrines like comity and jus cogens are more likely to achieve coherence than fragmentation. Disparate settlement regimes (institutions) need to be synchronised to enhance the settlement of international disputes using such conflict rules (norms), as do international and regional instruments of agreement and cooperation given the disconnect between the creation of dispute settlement institutions and the rules governing their interaction.

It is in most states' interests to comply with international law as good international citizens, not just so that the merits are on their side when they need to invoke it themselves, but submission to international adjudication also 'enhances the credibility of international commitment' of states (Heifer \& Slaughter, 2005). International law lends a measure of predictability and certainty to resolving a wide range of international disputes (Franklin, 2005). Even though cases such as the MOX Plant appear to point the other way, the display of arbitral deference to the ECJ's jurisdiction stands as something of a banner for comity as a conflict rule on the rise. International law agencies and institutions must aim to achieve coherence, rather than fragmentation, however imperfectly that endeavour is honoured in the observance. The aim of harmony in international law is akin to the aim of justice generally. No legal system will ever deliver perfect justice, but it must attain to something like it in the vast majority of its transactions. Without goodwill, law is only able to do so much. International law is no different.

\section{Acknowledgements}

I would like to thank Professor Natalie Klein of the University of New South Wales, whose clarity and passion rekindled my interest in International Law during my Masters of Law degree. I also wish to thank Allison Sadick for her valuable input in proof-reading and assisting me with the formatting of this article for publication.

\section{References}

Allsop, J. J. (2015). Comity and commerce. Federal Judicial Scholarship, 27, [2].

Armstrong, D. (2011). Evolving Conceptions of Justice in International Law. Review of International Studies, 37, 2121-2136. https://doi.org/10.1017/S0260210511000350

Benvenisti \& Downs (2007). The Empire's New Clothes: Fragmentation of International Law. Stanford Law Review, 60, 595-599, 596.

Black, R. C., \& Epstein, L. (2007). (Re-)Setting the Scholarly Agenda on Transjudicial Communication Law \& Social Inquiry, 32, 791-807. https://doi.org/10.1111/j.1747-4469.2007.00077.x

Blackaby, N., Partasides, Q. C. C., Redfern, A., \& Hunter, M. (2015). Redfern and Hunter on International Arbitration. Oxford: Oxford University Press.

Born, G. B. (2012). A New Generation of International Adjudication. Duke Law Journal, 61, 775-794.

Born, G. B. (2016). International Commercial Arbitration: Law and Practice. The Netherlands: Wolters Kluwer.

Boyle, A. E. (1997). Dispute Settlement and the Law of the Sea Convention: Problems of Fragmentation and Jurisdiction. The International and Comparative Law Quarterly, 46, 37-39. https://doi.org/10.1017/S0020589300060103

Bradley, C. A. (1997). The Charming Betsy Canon and Separation of Powers: Rethinking the Interpretive Role of International Law. Georgetown Law Journal, 86, 479.

Burchill, R. (2011). The Value of Dissonance: Regional Arrangements and the Pursuit of Harmony. Harmony and Dissonance in International Law, 105, 309-310. https://doi.org/10.5305/procannmeetasil.105.0309

Charney J.I. (1995). Central East Asian Maritime Boundaries and the Law of the Sea. The American Journal of International Law, 89, 724-727. https://doi.org/10.2307/2203934

Charney, J. I. (1996). The Implications of Expanding International Dispute Settlement Systems: The 1982 Convention on the Law of the Sea. American Journal of International Law, 90, 69-75. https://doi.org/10.2307/2203752

Chinkin, C., \& Sadurska, R. (1991). The Anatomy of International Dispute Resolution. Ohio State Journal of Dispute Resolution, 39, 39.

Dunoff, J. L., \& Trachtman, J. P. (2009). Ruling the World? Constitutionalism, International Law, and Global Governance. Cambridge: Cambridge University Press. https://doi.org/10.1017/CBO9780511627088

Egede, E., \& Sutch, P. (2013). The Politics of International Law and International Justice Book. Edinburgh: Edinburgh University Press.

Franklin, C. (2005). Flexibility vs. Legal Certainty, Article 307 EC and Other Issues in the Aftermath of the Open Skies Cases. European Foreign Affairs Review, 10, 79-115. 
Giorgetti, C. (2012). The Rules, Practice, and Jurisprudence of International Courts and Tribunals. Leiden: Brill. https://doi.org/10.1163/9789004194830

Goh, G. (2002). Australia's Participation in the WTO Dispute Settlement System. Federal Law Review. 30(1), 203. https://doi.org/10.1177/0067205X0203000107

Gutterman, E. (2012). What is at Stake in the Global Constitutionalism Debate? International Studies Review, 14, 182-183. https://doi.org/10.1111/j.1468-2486.2012.01090.x

Heifer, L. R., \& Slaughter A. (2005). Why States Create International Tribunals: A Response to Professors Posner and Yoo. California Law Review, 93, 899-955.

Hufnagel, S. (2017). Regulation of cross-border law enforcement: 'locks' and 'dams' to regional and international flows of policing. Global Crime, 18, 218. https://doi.org/10.1080/17440572.2017.1345681

Jenks, C. W. (1953). The Conflict of Law-Making Treaties. British Yearbook of International Law, 30, 403.

Klein, N. (2014). The Effectiveness of the UNCLOS Dispute Settlement Regime: Reaching for the Stars? The Effectiveness of International Law, 108, 359-362. https://doi.org/10.5305/procannmeetasil.108.0359

Koskenniemi, M. (2007). The Fate of Public International Law: Between Technique and Politics. The Modern Law Review, 70, 1-7. https://doi.org/10.1111/j.1468-2230.2006.00624.x

Koskenniemi, M. et al (2006) Fragmentation of International Law: Difficulties arising from the Diversification and Expansion of International Law Report of the Study Group of the International Law Commission; International Law Commission Fifty-Eighth Session Geneva 2006, UN Document No. A/CN.4/L.682.

Koskenniemi, M., \& Leino, P. (2002). Fragmentation of International Law? Postmodern Anxieties. Leiden Journal of International Law, 15, 553-555. https://doi.org/10.1017/S0922156502000262

Lando, M. (2017). Compliance with Provisional Measures Indicated by the International Court of Justice. Journal of International Dispute Settlement, 8, 22-25. https://doi.org/10.1093/jnlids/idv029

McInerney-Lankford, S. (2012). Fragmentation of International Law Redux: The Case of Strasbourg. Oxford Journal of Legal Studies, 32, 609-632. https://doi.org/10.1093/ojls/gqs014

Meier, H. (1982). Extraterritorial Jurisdiction. American Journal of International Law, 76, 280-281. https://doi.org/10.2307/2201454

Murphy, S. D. (2012). The International Court of Justice in Valencia-Ospina, E. and Malintoppi, L. eds., International Litigation in Practice. Leiden: Brill.

Nygh, P. and Butt, P. (1997). Butterworths Australian Legal Dictionary. Sydney: Butterworths.

Oxman, B. H. (2001). Complementary Agreements and Compulsory Jurisdiction. The American Journal of International Law, 95, 277-278. https://doi.org/10.2307/2661397

Paul, J. R. (1991). Comity in International Law. Harvard Law Review, 32, 1-20.

Posner, E. A. (2009). The Perils of Global Legalism. Chicago, IL: University of Chicago Press. https://doi.org/10.7208/chicago/9780226675923.001.0001

Posner, E. A. et al (2005). Judicial Independence in International Tribunals. California Law Review, 93, 1-174.

Roberts A. (2011). Comparative International Law? The Role of National Courts in Creating and Enforcing International Law. The International and Comparative Law Quarterly, 60, 57-79. https://doi.org/10.1017/S0020589310000679

Romano, C. P. et al (2014). The Oxford Handbook of International Adjudication. Oxford: Oxford University Press.

Sadat, L. N. (2013). Crimes Against Humanity in the Modern Age. The American Journal of International Law, 107, 334. https://doi.org/10.5305/amerjintelaw.107.2.0334

Schultz, T., \& Ridi, N. (2017). Comity and International Courts and Tribunals. Cornell International Law Journal, 50, 577-578. https://doi.org/10.31228/osf.io/9djt2

Shany, Y. (2005). Contract Claims vs. Treaty Claims: Mapping Conflicts between ICSID Decisions on Multisourced Investment Claims. The American Journal of International Law, 99, 835-850. https://doi.org/10.2307/3396671

Shany, Y. (2009). National Courts as International Actors: Jurisdictional Implications. Federalismi 1. https://doi.org/10.2139/ssrn.1292056

Slaughter, A. (2004). A New World Order. Princeton, NJ: Princeton University Press 
Squatrito, T. (2018). Amicus Curiae Briefs in the WTO DSM: Good or Bad News for Non-State Actor Involvement? World Trade Review, 17, 65-89. https://doi.org/10.1017/S1474745617000052

Tanaka, Y. (2018). The Peaceful Settlement of International Disputes. Cambridge, Cambridge University Press. https://doi.org/10.1017/9781316687062

United Nations Convention on the Law of the Sea (Montego Bay, 10 December 1982, in force 16 November 1994) 1833 UNTS 396.

Wouters, J. et al (2011). The Europeanisation of International Law: The Status of International Law in the EU and its Member States, The Hague: Cambridge University Press.

\section{Notes}

Note 1. International dispute settlement does not always purport to be comprehensive. For example, in international commercial arbitration, parties routinely limit the kind of disputes they want to refer to arbitration by prior agreement. The ensuing arbitration cannot be criticised for not dealing with claims excluded by agreement. Arbitration may still be said to provide a comprehensive resolution of the agreed claims in dispute.

Note 2. MOX Plant case, Request for Provisional Measures Order (Ireland v. United Kingdom) (3 December 2001) International Tribunal for the Law of the Sea, (2005) 126 ILR 273; MOX Plant case (Ireland v. United Kingdom) (Arbitral Tribunal Constituted under Article 287 and Annex VII of the UN Law of the Sea Convention), Order No. 6 of 6 June 2008 (Termination of Proceedings).

Note 3. Governed by the Claims Settlement Declaration in the Declaration of the Government of the Democratic and Popular Republic of Algeria (General Declaration) (1981) 20 ILM, p. 224 (the Algiers Accord).

\section{Copyrights}

Copyright for this article is retained by the author(s), with first publication rights granted to the journal.

This is an open-access article distributed under the terms and conditions of the Creative Commons Attribution license which permits unrestricted use, distribution, and reproduction in any medium, provided the original work is properly cited. 